\title{
The largest known odonate in China: Hsiufua chaoi Zhang et Wang, gen. et sp. nov. from the Middle Jurassic of Inner Mongolia
}

\author{
ZHANG HaiChun $^{1 *}$, ZHENG DaRan ${ }^{1,2}$, WANG Bo ${ }^{1}$, FANG Yan $^{1} \&$ JARZEMBOWSKI Edmund A ${ }^{1}$ \\ ${ }^{1}$ State Key Laboratory of Palaeobiology and Stratigraphy, Nanjing Institute of Geology and Palaeontology, Chinese Academy of Sciences, \\ Nanjing 210008, China; \\ ${ }^{2}$ Graduate University of the Chinese Academy of Sciences, Beijing 100049, China
}

Received June 26, 2012; accepted October 19, 2012; published online November 27, 2012

\begin{abstract}
A new genus and species, Hsiufua chaoi Zhang et Wang, is established based on a forewing from the Middle Jurassic Haifanggou Formation in Inner Mongolia, China and attributed to Campterophlebiidae, Isophlebioidea, Odonata. It is the largest odonate known in China and the fourth in the world in terms of forewing length. The maximum size (based on forewing length) of Odonata is smaller in the Permian than in the Mesozoic which is probably due to competition for prey between Odonata and Protodonata in the Permian. The reason that the maximum size of Jurassic odonates is larger than that of their extant relatives is most probably less competition and lower predation pressure from contemporary aerial vertebrates.
\end{abstract}

Hsiufua chaoi Zhang et Wang, new genus and species, largest odonate, Middle Jurassic, China

Citation: Zhang H C, Zheng D R, Wang B, et al. The largest known odonate in China: Hsiufua chaoi Zhang et Wang, gen. et sp. nov. from the Middle Jurassic of Inner Mongolia. Chin Sci Bull, 2013, 58: 1579-1584, doi: 10.1007/s11434-012-5567-3

Insects constitute the largest and most diverse group of organisms and over one million species have been described in the Class Insecta. They are the only invertebrates that can fly and the earliest animals to rule the air. They occurred much earlier and have a longer geological record than flying vertebrates. Winged insects had appeared at least by the end of the Early Carboniferous (320-300 Ma) [1], and probably as early as in the Early Devonian (about $400 \mathrm{Ma}$ ) [2]. Among vertebrates, pterosaurs are the earliest fliers and are known from the Middle Triassic (mid-Norian, about $210 \mathrm{Ma}$ ) [3]; birds appeared in the Late Jurassic (about $150 \mathrm{Ma}$ ) [4] or later [5], and bats first occur in the Early Eocene (52.5 Ma) [6].

Most extant insects have a body length of 5-15 $\mathrm{mm}$ and a wingspan of $15-45 \mathrm{~mm}$. In general, only a minority of insects are comparatively large. The stick insect Phobaeticus chani Bragg from Borneo is the world's longest extant insect with a maximum body length of $357 \mathrm{~mm}$ [7]; the owlet

*Corresponding author (email: hczhang@nigpas.ac.cn) moth Thysania agrippina (Cramer) from Central and South America is the world's broadest extant insect with a wingspan of up to $360 \mathrm{~mm}$ [8]. The Atlas Moth, Attacus atlas (Linnaeus), is the largest extant insect in China with a wingspan of up to $240 \mathrm{~mm}$ [9].

The superorder Odonatopera includes the orders Geroptera, Protodonata and Odonata [10]. The Geroptera lived in the early Late Carboniferous (Namurian), the Protodonata in the Late Carboniferous-Permian, and the Odonata from the Permian to the present [10] now comprising three suborders: Anisoptera (dragonflies), Zygoptera (damselflies) and Anisozygoptera (damsel-dragonflies). The so-called Palaeozoic "giant dragonflies" are not true dragonflies but members of the Protodonata: Meganeuridae. The Early Permian meganeurid Meganeuropsis permiana Carpenter from the USA has a wingspan of up to $710 \mathrm{~mm}$ and is by far the largest known insect in the world [10]; the late Carboniferous meganeurid Shenzhousia qilianshanensis Zhang et al. [11] is the largest insect found in China with a wingspan of 400-500 mm. 


\section{Material and methods}

The specimen NIGP156221, part and counterpart, is a damsel-dragonfly forewing collected from the Middle Jurassic Haifanggou Formation of Daohugou Village, Wuhua Township, Ningcheng County, Chifeng City, Inner Mongolia, China. The part is a nearly complete forewing with the middle fractured and damaged, the apical 1/3rd damaged near the posterior margin and the wing apex missing. The counterpart is incomplete with only the wing apex preserved. The photograph of the whole specimen was taken using a Canon 5D camera. The specimen was examined dry and under alcohol, using a Nikon SMZ1000 stereomicroscope and drawings were made with the aid of a camera lucida. The photographs were prepared using a digital camera (DXM1200) connected to the above stereomicroscope, and the line drawings were finalised using photographs and image-editing software (CorelDRAW 9.0 and Adobe Photoshop $\mathrm{CS})$. The specimen is housed at the Nanjing Institute of Geology and Palaeontology, Chinese Academy of Sciences.

The nomenclature of the dragonfly wing venation used in this paper is based on the interpretations of Riek [12] and Riek and Kukalová-Peck [13], as amended by Nel et al. [14] and Bechly [15]. We use the following standard abbreviations: AA, anal anterior; AP, anal posterior; Arc, arculus; $\mathrm{Ax} 0 \mathrm{Ax} 1 \mathrm{Ax} 2$, primary antenodal cross-veins; $\mathrm{CuAa}$, distal branch of cubitus anterior; $\mathrm{CuAb}$, proximal branch of cubitus anterior; IR1, IR2, intercalary radial veins; MAa, distal branch of median anterior; MAb, posterior branch of median anterior; MP, median posterior; N, nodus; "O", oblique vein; $\mathrm{Pt}$, pterostigma; RA, radius anterior; $\mathrm{RP}$, radius posterior; Su.C, subdiscoidal cell; D.C., discoidal cell. The higher classification of fossil and extant Odonatoptera is based on the phylogenetic system of Bechly [15].

\section{Systematic palaeontology}

\section{Superorder Odonatoptera Martynov, 1932 \\ Order Odonata Fabricius, 1793 \\ Superfamily Isophlebioidea Handlirsch, 1906 \\ Family Campterophlebiidae Handlirsch, 1920 \\ Genus Hsiufua Zhang et Wang, gen. nov.}

Type species: Hsiufua chaoi Zhang et Wang, gen. et sp. nov.

Etymology: The generic name is dedicated to the late and famous Chinese entomologist, Professor Chao Hsiu-fu.

Diagnosis: Forewing characters only. Forewing extremely narrow and elongate. Gaff (basal part of $\mathrm{CuA}$ ) straight and very long; proximal part of area between MP and $\mathrm{CuA}$ about three times as wide as that between MA and MP; Ax1 basal of arculus, far from wing base and nearly perpendicular to $\mathrm{ScP}$; $\mathrm{Ax} 2$ subparallel to $\mathrm{Ax} 1$, and slightly closer to wing base than to nodus; a secondary longitudinal vein in anal area parallel to AA and posterior wing margin; a long single cell covering basal part of area between MP and $\mathrm{CuA}$, just distal of gaff; area between IR2 and RP3/4 clearly broadened in its mid part and greatly constricted near wing margin; CuAa short; pterostigma narrow and elongate, brown, far from wing apex, with a long, central unpigmented area; no cells below pterostigma; IR2 not originating from RP3/4; oblique vein "O" very oblique and strong, only four cells distal of base of RP2.

Hsiufua chaoi Zhang et Wang, gen. et sp. nov. (Figures 1 and 2)

Etymology: The specific name is dedicated to the late and famous Chinese entomologist, Professor Chao Hsiu-fu.

Material: A nearly complete forewing (holotype), part and counterpart, as noted above.

Locality and horizon: Daohugou village, Wuhua Township,

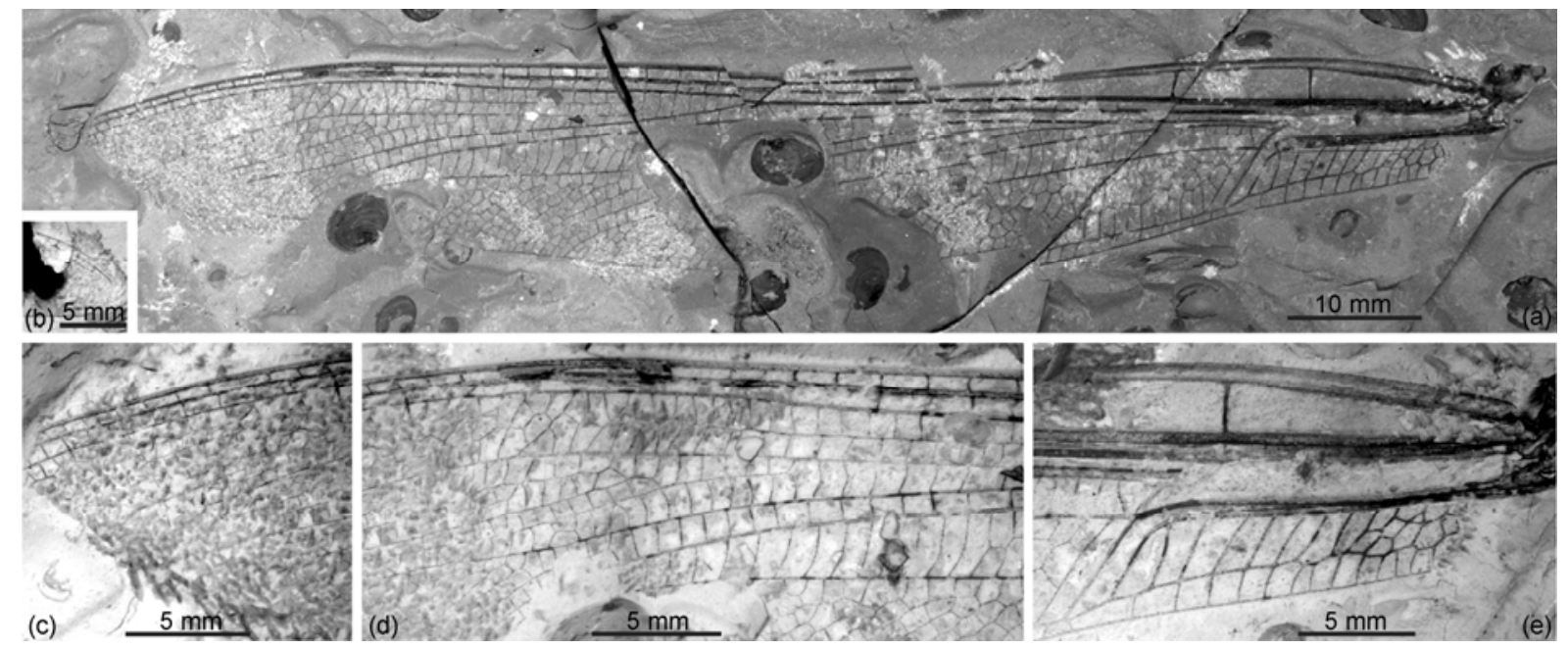

Figure 1 Photographs of forewing of Hsiufua chaoi Zhang et Wang, gen. et sp. nov. (a) Photograph of the whole specimen 156221a (dry); (b) photograph of specimen 156221b (under alcohol); (c) photograph of specimen 156221a, apical area (under alcohol); (d) photograph of specimen 156221a, pterostigmal area (under alcohol); (e) photograph of specimen 156221a, basal area (under alcohol). 
Ningcheng County, Chifeng City, Inner Mongolia, China; Middle Jurassic Haifanggou Formation.

Description: Forewing hyaline, $107.6 \mathrm{~mm}$ long, 14.3 $\mathrm{mm}$ wide. Distance between wing base and arculus 13.8 $\mathrm{mm}$, between arculus and nodus $37.1 \mathrm{~mm}$; distance between pterostigmal base and nodus $28.9 \mathrm{~mm}$, between pterostigmal apex and wing apex $20.7 \mathrm{~mm}$; distance between Ax1 and wing base $12.9 \mathrm{~mm}$, between Ax1 and Ax2 $10.1 \mathrm{~mm}$, between Ax2 and nodus $28.3 \mathrm{~mm}$; Ax1 $1.2 \mathrm{~mm}$ basal of arculus, and nearly perpendicular to $\mathrm{ScP}$; Ax2 slightly oblique towards wing apex; pterostigma $6.7 \mathrm{~mm}$ long, about $1.1 \mathrm{~mm}$ wide, brown with central unpigmented area about half as long as pterostigma; neither pterostigmal brace nor cells below it present; veins $\mathrm{C}$ and RA not widened along pterostigma; median and submedian spaces free of crossveins; discoidal space basally open; subdiscoidal cell free of cross-veins, narrow, elongate and nearly trapezoidal, 4.2 $\mathrm{mm}$ long, and $0.8 \mathrm{~mm}$ wide in mid part; a long single cell covering whole area between MP and $\mathrm{CuA}$, just distal of gaff; AA distally strongly bent towards posterior wing margin at $\mathrm{CuP}$, more or less parallel to $\mathrm{CuA}$, then distally fused with a secondary longitudinal vein into a strong vein parallel to posterior wing margin and distally ending in $\mathrm{CuA}$; anal area (not preserved basally) with 3 rows of cells basally and 2 rows of large cells distally; gaff $5.2 \mathrm{~mm}$ long; basal cell between MP and CuA $5.6 \mathrm{~mm}$ long, $0.8 \mathrm{~mm}$ wide; basal part of area between MP and $\mathrm{CuA} 2.7$ times as broad as that between MA and MP; CuAa parallel to posterior wing margin, then progressively weakening and fused with posterior wing margin, $16.7 \mathrm{~mm}$ long, with one row of cells below $\mathrm{CuA} ; \mathrm{CuAb}$ very short and directed towards posterior wing margin; area between $\mathrm{CuA}$ and $\mathrm{MP}$ with 3 rows of large cells basally; area between MP and posterior wing margin with 6 rows of cells at same level as end of $\mathrm{CuAa}$; MP nearly straight, ending in posterior wing margin far distal of nodus, and $67.8 \mathrm{~mm}$ from wing base (at $63 \%$ of wing length); MA slightly arched and subparallel to MP; one row of cells in post-discoidal area, greatly constricted near wing margin; base of RP3/4 $14.0 \mathrm{~mm}$ distal of arculus and 23.0 $\mathrm{mm}$ basal of nodus; vein $\mathrm{CP}$ bent towards $\mathrm{ScP}$, not preserved near nodus; subnodus very oblique; PR2 aligned with subnodus; oblique vein "O" ill-preserved, 4 cells and $6.0 \mathrm{~mm}$ distal of base of RP2; RP2 slightly arched in mid part; area between RP2 and IR2 with one row of cells from their bases to level of pterostigma, distally widened with 10-12 rows of cells (as estimated) near posterior wing margin; IR1 subparallel to RP1, nearly straight basally; base of IR1 $8.4 \mathrm{~mm}$ distal of base of RP2; area between MA and RP3/4 very narrow basally with only one row of cells, greatly widened distally but badly preserved near wing margin with 13 rows of cells observed (over 20 rows of cells estimated); IR2 without origin on RP3/4; area between RP3/4 and IR2 gradually widened towards its middle, but basally and distally constricted, with 2 rows of cells in mid part, and only one row basally and distally; area between IR1 and RP2 progressively widened distally, with 2 secondary longitudinal veins, and 6 rows of cells distally (but not preserved near wing margin); area between IR1 and RP1 slightly widened distally (not preserved near wing margin), with a weak secondary longitudinal vein, and 7 rows of cells observed distally.

Comparison and remarks: The genus undoubtedly belongs to Campterophlebiidae based on the following characteristics in the forewing: the discoidal cell is basally open, vein MAb is not far from the arculus, and no secondary antenodal cross-veins are present between $\mathrm{C}$ and $\mathrm{ScP}[16,17]$. The Campterophlebiidae is the largest damsel-dragonfly family living in Eurasia in the Late Triassic-Cretaceous and includes 49 species in 30 genera [17-19]. So far, 11 species in 7 genera have been discovered in the Middle Haifanggou

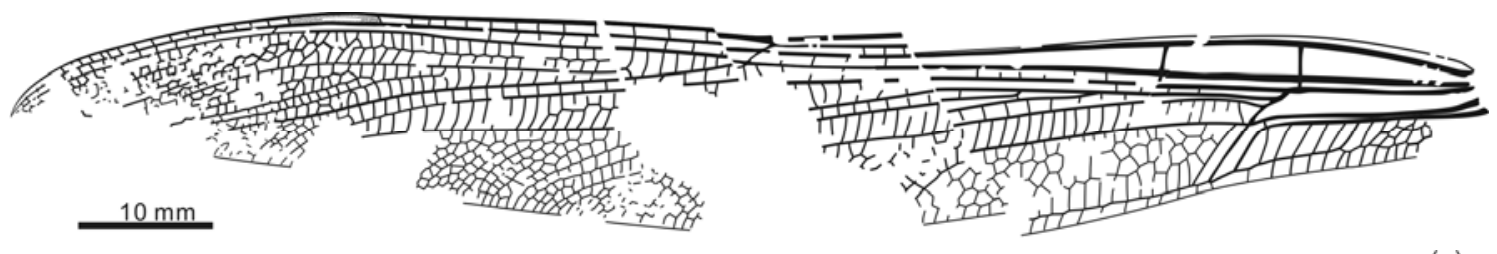

(a)

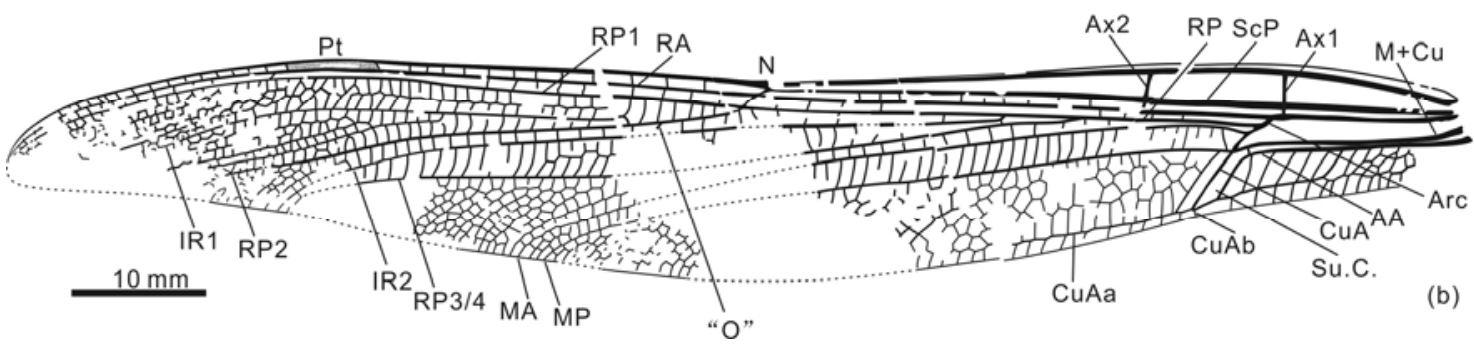

Figure 2 Line drawing (a) and reconstruction (b) of forewing of Hsiufua chaoi Zhang et Wang, gen. et sp. nov. 
Formation of Daohugou in Inner Mongolia [18,20-25] and they are: Amnifleckia guttata Zhang, Ren and Cheng, 2006, Amnifleckia splendida Huang et al., 2006, Bellabrunetia catherinae Fleck et Nel, 2002, Ctenogampsophlebia reni Petrulevicius, Huang et Nel, 2011, Parabrunetia celinea Huang et al., 2006, Qibinlina sinica Huang et Nel 2009, Sinokaratawia daohugouica Zhang, Ren et Pang, 2008, Sinokaratawia gloriosa Zhang, Ren et Pang, 2008, Sinokaratawia magica Zhang, Ren et Pang, 2008, Sinokaratawia prokopi Nel, Huang et Lin, 2007, and Zygokaratawia reni Nel, Huang et Lin, 2008. These insects are well preserved due to the special taphonomic conditions there [26].

The new genus has a very narrow and elongate forewing which is at least $20 \%$ longer than that of other campterophlebiid genera and possesses a much higher length/ width ratio (up to 7.5 in the new genus and less than 6.3 in the other genera). The unpigmented area in the pterostigma is sharply and evenly separated from the brown pterostigma (Figure 1(d)), indicating that the centrally unpigmented area is a diagnostic character of the new genus and its presence is not the result of poor preservation of the pterostigma. The above features easily differentiate the new genus from all other campterophlebiid genera. The forewing of the new genus is very similar to that of Bellabrunetia Fleck et Nel from the same locality and horizon (originally given as the Yixian Formation in Liaoning Province, China by mistake) but differs in that the former is much longer than the latter (the former is as wide as but $20 \%$ longer than the latter); has a nearly straight antenodal cross-vein Ax2 about midway between the wing base and nodus (the latter has a distinctly oblique $\mathrm{Ax} 2$ at a basal 1/3rd position between the wing base and nodus); has the basal part of the area between MP and $\mathrm{CuA}$ about 3 times as broad as that between MA and MP (the latter twice); and has 4 cells between oblique vein "O" and base of RP2 (the latter has only 2).

\section{Discussion}

The order Odonata includes about 5900 extant species [27], and their body length varies from $30 \mathrm{~mm}$ to $90 \mathrm{~mm}$. The extant largest odonate is the damselfly Megaloprepus caerulatus (Drury) living in Central and South America with a wingspan of up to $190 \mathrm{~mm}$ [28]. In the evolutionary history of the Odonata, however, some species had a distinctly much larger size: the Middle Triassic Triadotypus guillaumei Grauvogel et Laurentiaux from France is the largest known with a forewing of $136 \mathrm{~mm}$ in length [29] and a wingspan of $280 \mathrm{~mm}$ (as estimated); the Middle Jurassic Hemerobioides giganteus Westwood from UK has a forewing of $120 \mathrm{~mm}$ in length (estimated) [30]; the Late Jurassic Isophlebia aspasia Hagen from Germany has a forewing of $110 \mathrm{~mm}$ in length [12] and a wingspan of $228 \mathrm{~mm}$ (estimated); and the Late Jurassic Aeschnogomphus kuempeli Bechly from Germany has a forewing of $106 \mathrm{~mm}$ in length and a wingspan of 220 mm [31]. Hsiufua chaoi Zhang et Wang described herein has a forewing of $107.6 \mathrm{~mm}$ in length and a wingspan of $225 \mathrm{~mm}$ (estimated), and is considered to be the world's fourth largest odonate and the largest one known from China.

Distinct changes in body size have occurred in the superorder Odonatoptera during its long evolutionary history. In the Late Carboniferous and Early Permian, some giant species appeared and are exemplified by the Late Carboniferous Meganeura monyi Brongniart with a wingspan of up to $650 \mathrm{~mm}$ [32] and the Early Permian Meganeuropsis permiana Carpenter with a wingspan of up to $710 \mathrm{~mm}$ [10]. After these periods, however, no odonatopterans with a wingspan greater than $300 \mathrm{~mm}$ are known from the fossil record [12,29-31]. The great change in insect size has been attributed to changes in the level of atmospheric oxygen: on this model, a great increase in the level of atmospheric oxygen in the Late Palaeozoic resulted in the appearance of giant insects and the subsequent decrease resulted in the loss of gigantism in insects [33,34]. It is estimated that atmospheric oxygen partial pressures in the late Palaeozoic were $27-35 \mathrm{kPa}$ greater than the current one at $21 \mathrm{kPa}$ [34-37] (Figure 3). Another hypothesis is that the lack of aerial vertebrate predators allowed these insects to evolve to their maximum size during the Carboniferous and Permian periods, and that the extinction and permanent disappearance of giant flying insects after the Permian is directly correlated with the predatory threat from the swifter and stronger aerial pterosaurs, birds and bats [38]. No comparatively large ground-dwelling insects are known from the late Palaeozoic fossils, perhaps because predators such as large amphibians, early reptiles, and large arachnids prohibited such a dramatic size increase [38]. Recent studies of some extant insects indicate that most insects develop smaller body sizes in hypoxia, whilst some develop and evolve larger sizes in hyperoxia $[39,40]$. Hence, it is reasonable to consider the hyperoxia in the late Palaeozoic atmosphere to be at least one important reason for the appearance of giant insects, and the subsequent appearance of their competitors and predators (pterosaurs, birds and bats) undoubtedly limited the maximum body size of insects. An analysis of changes in the wing length of the largest odonatopterans through their geological history demonstrates that the level of atmospheric oxygen is only one of the controlling factors limiting maximum body size of insects [41]. A recent study shows [42] that changes in wing length of the largest insects from the Middle Carboniferous to the Late Jurassic are consistent with changes in the level of atmospheric oxygen shown by the GEOCARBSULF model [37]. If the changes in atmospheric oxygen partial pressures in the Phanerozic are correctly predicted by the GEOCARBSULF model (Figure 3), then the fact that the maximum size (forewing length) of Odonata is smaller in the Permian than in the Mesozoic [41] probably results from earlier competition for food resources between Odonata and Protodonata. On the other hand, atmospheric oxygen partial pressures in the Jurassic 


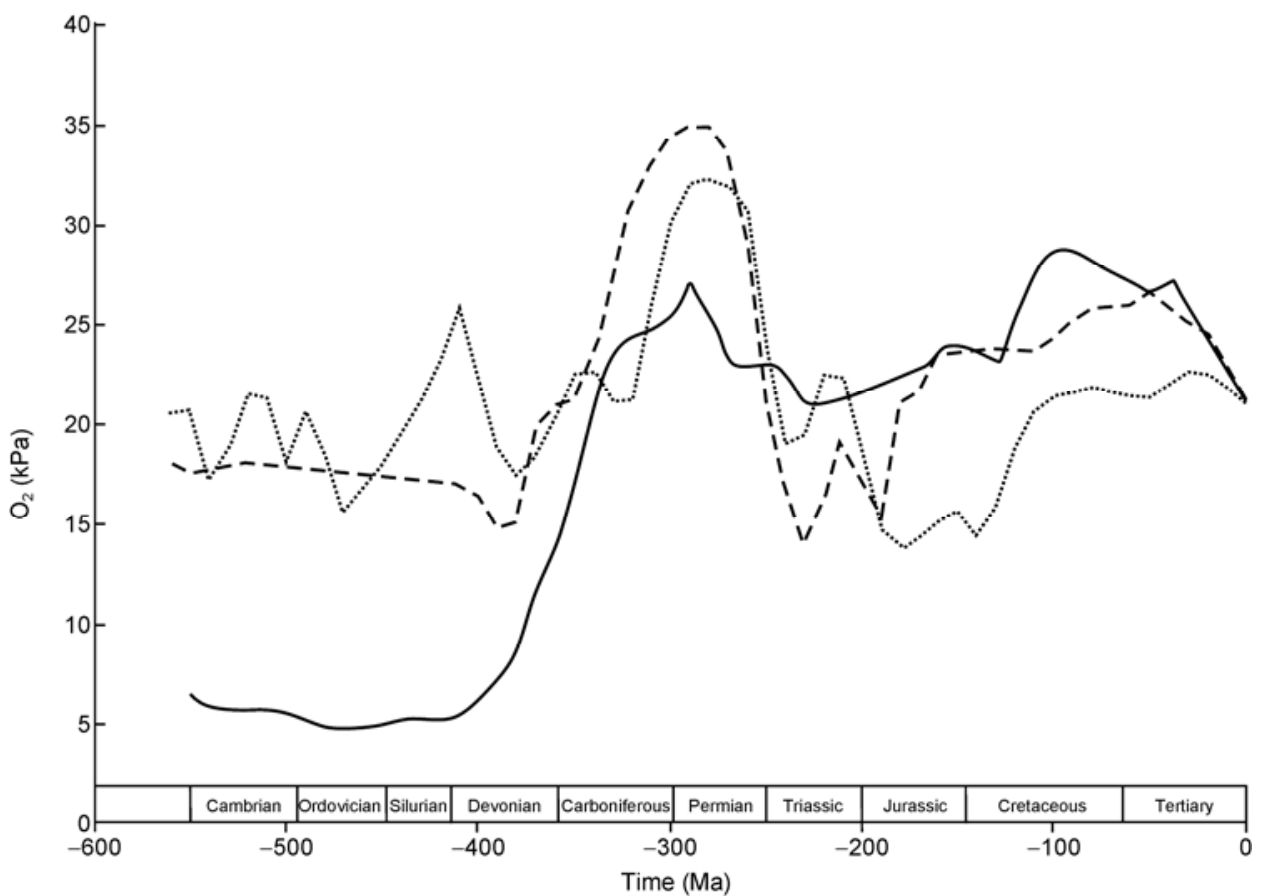

Figure 3 Various patterns of modelled $\mathrm{aPO}_{2}$ during the Phanerozoic. Solid line (Bergman et al., 2004) [36], dotted line (Berner, 2009) [37], dashed line (Berner and Canfield, 1989) [35].

are thought to be lower than the current one at $21 \mathrm{kPa}$ [37], but the maximum size of Jurassic odonates is greater than that of their extant relatives. It most probably results from less competition and lower predation pressure from aerial vertebrates in the Jurassic, including comparatively low pterosaur diversity and more limited flying ability in early birds which appeared during the Late Jurassic [4] (or later [5]).

The authors thank two anonymous reviewers for their valuable comments on this paper and the editors who greatly improved the manuscript. This work was supported by the National Basic Research Program of China (2012CB821900), the National Natural Science Foundation of China (41272013, 41002006 and J0930006) and the Chinese Academy of Sciences Visiting Professorship for Senior International Scientists (2011t2z04).

1 Brauckmann C, Brauckmann B, Gröning E. The stratigraphical position of the oldest known Pterygota (Insecta, Carboniferous, Namurian). Ann Soc Geol Belg, 1996, 117: 47-56

2 Engel M S, Grimaldi D. New light shed on the oldest insect. Nature, 2004, 427: 627-630

3 Jenkins F A Jr, Shubin N H, Gatesby S M, et al. A diminutive pterosaur (Pterosauria: Eudimorphodontidae) from the Greenlandic Triassic. Bull Mus Comp Zool, Harvard, 2001, 56: 151-170

4 Feduccia A. The Origin and Evolution of Birds. 2nd ed. New Haven: Yale University Press, 1999. 1-466

$5 \mathrm{Xu} \mathrm{X}$, You H, Du K, et al. An Archaeopteryx-like theropod from China and the origin of Avialae. Nature, 2011, 475: 465-470

6 Simmons N B, Seymour K L, Habersetzer J, et al. Primitive early Eocene bat from Wyoming and the evolution of flight and echolocation. Nature, 2008, 451: 818-821

7 Hennemann F H, Conle O V. Revision of Oriental Phasmatodea: The tribe Pharnaciini Günther, 1953, including the description of the world's longest insect, and a survey of the family Phasmatidae Gray,
1835 with keys to the subfamilies and tribes (Phasmatodea: "Anareolatae": Phasmatidae). Zootaxa, 2008, 1906: 1-316

8 Ohl M, Thiele K. Estimating body size in apoid wasps: The significance of linear variables in a morphologically diverse taxon (Hymenoptera, Apoidea). Zoosystemat Evol, 2007, 82: 110-124

9 Wu C S. Class Insecta: Order Lepidoptera. In: Zheng L Y, Gui H, eds. Insect Classification (II) (in Chinese). Nanjing: Nanjing Normal University Press, 1999. 805-821

10 Grimaldi D, Engel M S. Evolution of the Insects. New York: Cambridge University Press, 2005. 1-755

11 Zhang Z J, Hong Y C, Lu L W, et al. Shenzhousia qilianshanensis gen. et sp. nov. (Protodonata, Meganeuridae), a giant dragonfly from the Upper Carboniferous of China. Prog Nat Sci, 2006, 16: 328-330

12 Riek E F. A new collection of insects from the Upper Triassic of South Africa. Ann Natal Mus, 1976, 22: 791-820

13 Riek E F, Kukalová-Peck J. A new interpretation of dragonfly wing venation based upon Early Carboniferous fossils from Argentina (Insecta: Odonatoidea) and basic characters states in pterygote wings. Can J Zool, 1984, 62: 1150-1166

14 Nel A, Martínez-Delclòs X, Paicheler J C, et al. Les 'Anisozygoptera' fossiles. Phylogénie et classification (Odonata). Martinia Hors Série 3, 1993. 1-311

15 Bechly G. Morphologische Untersuchungen am Flügelgeäder der rezenten Libellen und deren Stammgruppenvertreter (Insecta; Pterygota; Odonata), unter besonderer Berücksichtigung der Phylogenetischen Systematik und des Grundplanes der Odonata. Petalura, 1996, Special Volume 2: 1-402

16 Nel A, Bechly G, Delclòs X, et al. New and poorly known Mesozoic damsel-dragonflies (Odonata: Isophlebioidea: Campterophlebiidae, Isophlebiidae). Palaeodiversity, 2009, 2: 209-232

17 Li Y J, Nel A, Ren D, et al. A new damsel-dragonfly from the Lower Cretaceous of China enlightens the systematics of the Isophlebioidea (Odonata: Isophlebioptera: Campterophlebiidae). Cret Res, 2012, 34: 340-343

18 Petrulevicius J F, Huang D Y, Nel A. A new genus and species of damsel-dragonfly (Odonata: Isophlebioidea: Campterophlebiidae) in the Middle Jurassic of Inner Mongolia, China. Acta Geol Sin, 2011, 85: 733-738 
19 Ren D, Shih C K, Gao T P, et al. Insect Fossil Treasures From the Mesozoic of Northeast China (in Chinese). Beijing: Science Press, 2012. 1-409

20 Fleck G, Nel A. The first isophlebioid dragonfly (Odonata: Isophlebioptera: Campterophlebiidae) from the Mesozoic of China. Palaeontology, 2002, 45: 1123-1136

21 Zhang B L, Fleck G, Huang D Y, et al. New isophlebioid dragonflies (Odonata: Isophlebioptera: Campterophlebiidae) from the Middle Jurassic of China. Zootaxa, 2006, 1339: 51-68

22 Nel A, Huang D Y, Lin Q B. A new genus of isophlebioid damseldragonflies (Odonata: Isophlebioptera: Campterophlebiidae) from the Middle Jurassic of China. Zootaxa, 2007, 1642: 13-22

23 Nel A, Huang D Y, Lin Q B. A new genus of isophlebioid damseldragonflies with "calopterygid"-like wing shape from the Middle Jurassic of China (Odonata: Isophlebioidea: Campterophlebiidae). Eur J Entom, 2008, 105: 783-787

24 Zhang B L, Ren D, Pang H. New isophlebioid dragonflies from the Middle Jurassic of Inner Mongolia, China (Insecta: Odonata: Isophlebioptera: Campterophlebiidae). Acta Geol Sin, 2008, 82: 11041114

25 Nel A, Bechly G, Delclòs X, et al. New and poorly known Mesozoic damsel-dragonflies (Odonata: Isophlebioidea: Campterophlebiidae, Isophlebiidae). Palaeodiversity, 2009, 2: 209-232

26 Wang B, Li J F, Fang Y, et al. Preliminary elemental analysis of fossil insects from the Middle Jurassic of Daohugou, Inner Mongolia and its taphonomical implications. Chin Sci Bull, 2009, 54: 783-787

27 Zhang Z Q. Phylum Arthropoda von Siebold, 1848. In: Zhang Z Q, ed. Animal biodiversity: An outline of higher-level classification and survey of taxonomic richness. Zootaxa, 2011, 3148: 99-103

28 Groeneveld L F, Clausnitzer V, Hadrys H. Convergent evolution of gigantism in damselflies of Africa and South America: Evidence from nuclear and mitochondrial sequence data. Mol Phylogenet Evol, 2006, 42: 339-346

29 Nel A, Bethoux O, Bechly G, et al. The Permo-Triassic Odonatoptera of the "Protodonate" grade (Insecta: Odonatoptera). Ann Soc entomol Fr, 2001, 37: 501-525
30 Handlirsch A. Die fossilen Insekten und die Phylogenie der rezenten Formen, Parts V-VII. Ein Handbuch fur Palaontologen und Zoologen. Leipzig: Wilhelm Engelmann, 1907, 641-1120

31 Bechly G. Two new fossil dragonfly species (Insecta: Odonata: Pananisoptera: Aeschnidiidae and Atassiidae) from the Solnhofen lithographic limestones (Upper Jurassic, Germany). Stuttgarter Beitr Naturk, Ser B, 2000, 288: 1-9

32 Carpenter F M. Studies on Carboniferous insects from Commentry, France; Part I. Introduction and families Protagriidae, Meganeuridae, and Campylopteridae. Geol Soc Am Bull, 1943, 54: 527-554

33 Graham J B, Dudley R, Aguilar N M, et al. Implications of the later Palaeozoic oxygen pulse for physiology and evolution. Nature, 1995, 375: $117-120$

34 Berner R A. GEOCARBSULF: A combined model for Phanerozoic atmospheric $\mathrm{O}_{2}$ and $\mathrm{CO}_{2}$. Geochim Cosmochim Acta, 2006, 70: 5653-5664

35 Berner R A, Canfield D E. A new model for atmospheric oxygen over Phanerozoic time. Am J Sci, 1989, 289: 333-361

36 Bergman N M, Lenton T M, Watson A J. COPSE: A new model of biogeochemical cycling over Phanaerozoic time. Am J Sci, 2004, 304: 397-437

37 Berner R A. Phanerozoic atmospheric oxygen: New results using the GEOCARBSULF model. Am J Sci, 2009, 309: 603-609

38 Bechly G. Evolution and systematics. In: Hutchins M, Evans A V, Garrison R W, et al., eds. Grzimek's Animal Life Encyclopedia. 2nd ed. Vol.3, Insects. Detroit: Gale, 2004. 7-16

39 Harrison J F, Kaiser A, VandenBrooks J M. Atmospheric oxygen level and the evolution of insect body size. Proc R Soc B, 2010, 277: 1937-1946

40 Verberk C E P, Bilton D T. Can oxygen set thermal limits in an insect and drive gigantism? PLoS One, 2011, 6: e22610

41 Okajima R. The controlling factors limiting maximum body size of insects. Lethaia, 2008, 41: 423-430

42 Clapham M E, Karr J A. Environmental and biotic controls on the evolutionary history of insect body size. Proc Natl Acad Sci USA, 2012, 109: 10927-10930

Open Access This article is distributed under the terms of the Creative Commons Attribution License which permits any use, distribution, and reproduction in any medium, provided the original author(s) and source are credited. 